MARKETING AND BRANDING
RESEARCH
INDUSTRIAL
MANAGEMENT
INSTITUTE

\title{
CSR in the banking sector: A legitimacy approach to the shareholders' and stakeholders' debate
}

\author{
Charbel Chedrawi* ${ }^{*}$ Souheir Osta \\ Saint Joseph University - Lebanon
}

\begin{abstract}
Keywords:

Legitimacy Theory,

Stakeholders,

Shareholders,

Corporate Social

Responsibility,

Banking Sector

Correspondence:

cchedrawy@hotmail.com

Globalization increased calls for corporations to use firms' resources to alleviate a wide variety of social problems taking into consideration that existing governments are unable or unwilling to deal with such problems. In this context, corporate social responsibility (CSR) in the banking sector became a strategic tool of legitimacy in parallel to the recognition of stakeholders' interests keeping the primacy of shareholders' interests. This article studies CSR in the Lebanese banking sector through Suchman's (1995) legitimacy approach to the shareholders' and stakeholders' debate. Using a qualitative approach, this paper discloses how the banking strategy in terms of CSR could respond to the process of legitimacy within the debate: "creating value for stakeholders creates value for shareholders"; and reveals how normative considerations are likely to modify substantially banks' behavior and practices.
\end{abstract}

(C)AIMI Journals

\section{Introduction}

CSR has become an essential activity in the agenda of many companies worldwide. For the World Business Council for Sustainable Development "It is the continuing commitment by business to behave ethically and to contribute to economic development, while improving the quality of life of workforce and their families as well as for the society at large" (Holme \& Watts, 2000, p. 8).

CSR serves to increase and to legitimize the economic performance of any given sector (Scholtens, 2006). The 2008 financial crisis drew attention to the necessity of CSR in the financial sector to increase the need for trust, accountability, and transparency. In fact, the need for ethical and responsible conduct has led to financial and investment processes to go beyond the protection of the legitimate interests of depositors and owners (Chiu, 2013). The 
contribution of financial institutions, such as banks, to CSR is significant considering the crucial role they play in financing the economical and developmental activities of the world (Chaudhury, Das, \& Sahoo, 2011).

According to Freeman (1984), an organization has to meet the multiple expectations of its various stakeholder groups, rather than the expectations of shareholders as in traditional shareholder theories only. The stakeholder theory emphasizes organizational accountability beyond economical or financial performance (Guthrie Petty, \& Ricceri, 2006). In fact, an organization might be engaged in CSR activities and reporting in order to discharge its accountability towards all stakeholders and therefore, legitimate their activities (Lindblom, 1994). These legitimization strategies imply that through CSR disclosure, organizations seek to communicate their legitimization actions (Deegan, 2002).

The provision of CSR information reduces the information asymmetry and places different kinds of stakeholders on the players' level. In return, an organization could expect certain benefits such as improving its image/reputation, attracting investors, lowering the cost of capital, improving the retention of employees, attracting prospective employees, and improving the relationship with stakeholders in order to gain their support and approval (Deegan, 2009; Gray, Owen, \& Adams, 1996). According to Hinson, Boateng, and Madichie (2010), for companies to behave responsibly, the stakeholder theory is to be built on the demand of stakeholders including employees, customers, community, and the environment; as for the legitimacy theory, it emphasizes a social contract between the business and society.

In this context, our research is a further investigation of the CSR and the legitimacy theory within the shareholders' and stakeholders' debate in a very active and competitive environment, the Lebanese banking sector, where banks are thriving their way toward excellence in their quest for competitive advantages. As a valid case study, the choice of Bank Audi S.A.L. being a local and regional renowned financial institution, it is the leader bank in the Lebanese Market in terms of banking and CSR initiatives. Using a qualitative approach through centered semi-structured interviews conducted with two shareholders, General Managers, and three directors involved in the CSR strategy (CSR, HR and IT), this paper reveals the actions and practices currently undertaken by the bank revealing all the complexity of these concepts.

In order to disclose how the Bank Audi's CSR strategy could respond to the process of legitimation within the shareholders' and stakeholders' debate, we first define the CSR in the banking sector and its principle, the legitimacy theory and some literature insights of the shareholders' and stakeholders' debate. Then we present our methodology and the context of this article along with a proper presentation of our results and findings, discussion, conclusion, implications, and limitations.

\section{The Literature Review}

\section{CSR and Legitimacy in the Banking Industry}

CSR includes the economic, legal, ethical, and philanthropic expectations that society has of organizations (Carroll, 1991). A socially responsible corporation need to adopt policies and business practices that go beyond the minimum legal requirement and contribute to the welfare of its stakeholders (Adewale \& Rahmon, 2014). For Dujmovic, Sinkovic, and 
Vitasovic (2010), CSR should represent kind of self-regulating mechanism built in everyday corporate business activities through which they monitor its devotion to law and ethical standards.

From a bank manager's view, CSR is one of the approaches that can enhance the reputation of a bank and acquire a higher sense of trust from the customers (Shen, $\mathrm{Wu}, \mathrm{Chen}$, \& Fang, 2016). It is particularly important for the banking industry because banks sell intangible products (services) to individuals who may not be equipped with financial knowledge. In fact, Tzu-Kuan Chiu (2013) argued that in addition to the role of an intermediary which channels savings into investments, the demand for ethical and responsible conduct has guided to financial and investment procedures indicating beyond the preservation of the legal interests of depositors and owners.

According to Suchman (1995), legitimacy theory helps organizations to gain acceptance in society, leading them to strive for compliance with socially determined norms, values, and beliefs. It implies that a "social contract" exists between a business organization and its respective societies (Deegan, 2006). Therefore, an organization needs to ensure that these terms are not breached in order to maintain a good state of legitimacy through which society allows the organization's continuity. Legitimacy theory considers society as a whole without considering individuals separately (Deegan, 2002), it is concerned with the relationship between the organization and society at large.

According to Lindblom (1994), legitimization strategies can be employed by adopting CSR activities and reporting. He suggested many legitimization strategies to be adopted by an organization in order to legitimize its operations within the society in which it operates: For instance, organization could educate relevant stakeholders about its actual performance; it could change the perceptions of relevant stakeholders about an underlying issue without changing the organization's behavior; it could seek to divert the attention to a favorable issue; and/or seek to change external expectations about the organization's performance.

Moir (2001) points out that legitimate business would act in a particular manner in order to satisfy the social expectation. Legitimacy theory supposes that companies will response pragmatically and strategically to societies' expectations to increase their compliance while safeguarding some freedom of action in their pursuit of profit (Kuznetsov \& Kuznetsova, 2012). With this regard, CSR projects are organizational means to comply with community expectations (Deegan, 2002; Waddock, 2004). Nevertheless, according to Asforth and Gibbs (1990), the legitimating process could be perceived as purposive, calculated by managers; what was taken for granted before is now subject to debate. In fact, developing CSR projects and categorizing them as a strategic activity no longer suffices to gain stakeholders' legitimacy. Corporations search for another form of legitimacy through their CSR activities: The moral legitimacy. Moral legitimacy is needed not only to get closer to new, silent stakeholders such as those coming from civil society but also to comply with new sustainability expectations among consumers, governments, and shareholders (Palazzo \& Scherer, 2006).

Moral legitimacy can be defined as "a positive normative evaluation of the organization and its activities" (Suchman, 1995), or as a "conscious moral judgments on the organization's outputs, procedures, structures, and leaders" (Palazzo \& Scherer, 2006); it is a judgment about 
whether a given activity is the right thing to do, resulting from organizational participation in explicit public discussion (Suchman, 1995).

CSR is, therefore, a mean to maintain strategic objectives; it's a company's response to the interests of its stakeholders (Freeman, 1984). In fact, managers become aware that the success of a company depends on the internal and external stakeholders and they are willing to consider their needs and expectations in order to make long term balance with the financial goals.

\section{CSR and the Stakeholders and shareholders Debate}

The shareholders' and stakeholders' theories are normative theories of CSR and business ethics, dictating what a corporation's role is to be. For Smith (2003), a manager's responsibility is to stabilize the shareholders' financial interests with stakeholders' interests (employees, customers, etc.), even if it decreases shareholder returns. Jones and Wicks (1999) asserts that, managers have a responsibility to both the corporation's shareholders and stakeholders that contribute to wealth-creating activities (Post, Preston, \& Sachs, 2002).

From the stakeholders' theory perspective, managers as agents of all stakeholders, have two responsibilities: To make certain of non-violation of stakeholders' ethical rights and to stabilize their legitimate interests when making decisions (Evan \& Freeman, 1988). For Smith (2003), the objective is to ensure the balance between profit maximization and the long-term continuity of the organization. In fact, building better relations with primary stakeholders like employees, customers, suppliers, and communities (Freeman, 1984) help to develop a valuable source of competitive advantage (intangible asset) which will certainly lead to increased financial returns.

However, for Friedman (1962) the only social responsibility of business refers to taking advantage of its resources and becoming involved in activities designed to increase its profits. In fact, shareholder theory asserts that the capital advanced by shareholders are assumed to be spent by managers only in ways that have been permitted by them. It stimulates them to expand profits only through legal, non-deceptive means (Friedman, 1962) and sometimes prevents giving corporate funds to things such as charitable projects or investing in enhancing employee morale (Bowie \& Freeman, 1992).

In this context, Smith (2003) mentioned that, sometimes the stakeholder theory does not demand that a company focus on profitability. Even though the stakeholder theory's ultimate objective is continuity and existence, it must be achieved by balancing the interests of all stakeholders including the shareholders, whose interests are usually addressed through profits. For Zattoni (2011), companies should maximize shareholder value and be responsible to a large number of stakeholders. In fact, from a CSR approach, companies not only have to maximize profits (economic responsibility), but they must also be responsive to national and international laws and regulations (legal responsibility), embrace those activities that are generally expected by society even if they are not codified into laws (ethical responsibility), and spend corporate resources in social activities not required by law in a moral or ethical sense (discretionary or philanthropic responsibility) (Carroll, 1979, 1991, 1993).

On this lens of view, the company is a social institution, and management must base the relationships between the firm and its stakeholders on the liberal notions of autonomy, 
solidarity, and fairness (Freeman, 1994; Jones, 1995). In fact, from an ethical perspective, the stakeholder theory suggests that all stakeholders have the same right to be behaved fairly by any organization (Deegan, 2009). Within the ethical perspective, managers of an organization are expected to manage the business for the benefit of all stakeholders, regardless of whether management of stakeholders leads to improved financial performance (Hasnas, 1998). In this perspective, the organization is not viewed as a mechanism which drives the maximization of shareholders' wealth, but rather as one which meets the expectations of all stakeholders.

This ethical perspective relates directly to the accountability model of stakeholder theory proposed by Gray et al. (1996) where organizations owes accountability to all its stakeholders rather than only to more powerful or financial stakeholders (Gray, Owen, Adams, 2010). The main limitation of the ethical perspective is the managers' challenge to treat all stakeholders fairly, especially when the stakeholders have different and contradictory interests. In this regard, Hasnas (1998) suggests that when these interests conflict, organization should manage to attain the optimal balance among them. Therefore, the CSR disclosure motivation is driven by the desire to be accountable to all stakeholders irrespective of their economic power. By engaging in the disclosing of CSR information, an organization clearly accepts its stakeholders' right to know about certain aspects of its operations.

Finally, shareholders are just one of the multiple stakeholder groups which can affect and be affected by business firms (Donaldson \& Preston, 1995; Freeman \& Reed, 1983).

\section{Research Questions}

The following research questions guided the study:

What are the main benefits of CSR in the banking sector?

How does CSR relate to the bank Legitimacy?

What are the CSR perceptions and their influence on stakeholder and shareholder's behavior and debate?

\section{Method}

In order to study CSR in the Lebanese banking sector from a legitimacy approach to the shareholders' and stakeholders' debate, we used an exploratory approach. Our methodology relied on qualitative data collection and analysis. These data were collected using centered semi-structured interviews with two shareholders/General Managers (GM1, GM2), and the Directors of HR, IT, and CSR (D1, D2, D3). The centered semi-structured interviews enable us to collect data adapted to case studies. Data collection took place between October 2016 and January 2017.

To the data collected during interviews, we added secondary data from several sources (written, reports, oral); data consolidation was carried out using NVivo. The main objective of this research is to highlight the social responsibility strategy at Bank Audi within the shareholders' and stakeholders' debate revealing how normative considerations are likely to modify substantially banks' behavior and practices from the legitimacy theory perspective.

\section{Context of the Study: Bank Audi S.A.L.}

Our research is a further investigation of CSR in the banking sector from a legitimacy perspective to the shareholders' and stakeholders' debate in Bank Audi S.A.L. the leader in 
the Lebanese banking sector, a locally and regionally renowned financial institution strongly engaged in CSR. In fact, Bank Audi operates in 11 countries in the MENAT region (Middle East, North Africa, and Turkey) in the GCC and in Europe.

The year 2016 was difficult for the entire Middle East and North Africa region. Nevertheless, Bank Audi recorded a rather good performance in 2016 and kept its leading market share (around 20\%) ranking first among Lebanese banks in terms of total assets (US\$ 44.4 billion dollars), shareholders' equity (US\$ 3.8 billion dollars), customers' deposits (US\$ 36 billion dollars), and consolidated net profits of US\$ 470 million dollars, rising by $17 \%$ relative to 2015. These results prove the bank's high resilience and its capacity to sustain favorable growth.

As for social responsibility, Bank Audi is also among the first banks in Lebanon to introduce CSR, advocating for a sustainable future for the community and meeting rigorous environmental and social standards. In fact, in 2012, Bank Audi was the first banking institution to pilot the ISO 26000 Social Responsibility Guidance in Lebanon and to become member of the Local Network Steering Committee of the UN Global Compact (UNGC).

The bank's commitment at the social level is more than clear in to the Bank's Chairman (Mr. Raymond Audi) from whom we quote the following: We consider our progress in the CSR domain as vitally important and we should continue working with internal and external stakeholders to ensure that our business practices have the most positive impact on the communities we serve. We remain firmly committed to contributing to a sustainable future for all our stakeholders.

\section{Results}

The results of our exploratory study within Bank Audi, the largest commercial bank in Lebanon, enabled us to highlight the bank's social responsibility strategy in the perspectives of legitimacy theory and its contribution to the shareholders' and stakeholders' debate. The results provided a significant overview of this subject.

The results of our research provided significant insight on the importance of CSR in Bank Audi, the role of CSR in implying higher shareholder wealth through legitimacy, and the impact of CSR in the banking industry and its positive effects on shareholder and stakeholder debate.

\section{CSR Strategy in Bank Audi}

Bank Audi is a socially responsible bank aware of the importance of CSR as a strategic tool in its relation with different stakeholders: "We remain firmly committed to our mission of contributing to a sustainable future for all our stakeholders over the coming years (DG1). Bank Audi has been trying to be more and more a socially responsible bank. There are definitely the efforts of making sure that the communities we serve are somehow addressed (GM2). It is in our mentality and culture; embedded in every aspect of the bank (GM1, GM2)".

The bank's Management is well aware of the main benefits of the CSR in the banking sector in general and in Bank Audi in particular: "I think CSR is the cost of doing business, it is part of doing business, you can label it like an operating cost, but it is not really an 
investment it will help in building our identity, like an investment in our brand, image ..." (GM2).

Continuous efforts were undertaken during the last period in enhancing and communicating the CSR strategy of Bank Audi: "The Bank is continuously exerting efforts toward enhanced CSR business processes; in fact we continue to further develop our operating reporting mechanism, which was voluntarily initiated few years ago, in line with best practices and international standards (e.g. Global Reporting Initiative Guidelines (GRIG4), International Standards (ISO 26000), and United Nations Global Compact (UNGC) principles" (D3, GM1).

The bank is aware of the importance of ICT tools in communicating the CSR strategy to all stakeholders: "We are cognizant that our success in spreading further awareness on the uptake of CSR will continue to expand through communication' (D3); “from e-newsletters, to our website, we use every ICT tools available in communicating our CSR strategy" (D2).

\section{Legitimacy Theory within Bank Audi's CSR Strategy}

The second conclusion is that Bank Audi is seeking legitimacy to reflect a positive evaluation of the bank and its activities while adopting CSR strategy and more precisely moral legitimacy (Suchman, 1995): "CSR is a part of the business existence of the company and legitimacy is the instinct of what you want to be" (GM2). "CSR is a must for any institution to gain legitimacy" (GM1, GM2, D3).

The relation between CSR and legitimacy in Bank Audi is strategic at all levels: "Our future sustainability will be determined by how we undertake environmental and social issues" (GM1): "By creating manifold economic opportunities, providing access to finance and innovation, and adapting to the needs of the marketplace and the local economy, we have strengthened various aspects of our economic involvement and amplified the positive spillovers we have on different stakeholders in order to guarantee legitimacy" (GM1, D3); "we are also aware that we have major direct and indirect impacts on the Lebanese economy, whether through creating new jobs and employment opportunities, enabling small businesses to thrive, or helping our local economy to prosper" (D1).

The scale of Bank Audi in Lebanon also reflects on its role and legitimacy: "As one of the largest financial institutions in Lebanon, our ability to magnify our social impact is based on leveraging the full power of our company to work with different stakeholders on constructing stronger communities and a more stable economy" (D3).

\section{Stakeholders and Shareholders Debate within Bank Audi's CSR Strategy}

Bank Audi clearly classify its shareholders among its internal stakeholders. The shareholders' involvement is materialized with the establishment of a CSR committee at the board of directors' level: "After the formation of the CSR unit in 2010, we established a CSR committee with ten members representing the various departments of the Bank and led by a shareholder/General Manager" (GM1); "the debate is continuous, our shareholders are considered among our internal stakeholders" (GM2, D3).

The Bank tries to balance value creation for its stakeholders among which figures its shareholders: "our regional competitive presence along with our economic growth and, we 
create value for our stakeholders" (GM1, GM2); "we continuously encourage more players to engage in social responsibility to ensure a better sustainable future" (GM1, D3); "since we aim to maintain long-term relationships with our partners to create sustainable positive value for society, we seek partners that share our vision and values" (GM1, D2).

In fact, the Bank is continuously involving its stakeholders in its CSR strategy: "we have centered our CSR in the inclusion of our stakeholders" (GM1, D3); "we have engaged them through a yearly Stakeholders' Panel (GM1, GM2, D3) to enrich our impact and understanding of the community needs" (D3); "This helped us connect in an open dialogue with a wide range of stakeholders (employees, customers, community representatives, and other financial institutions) to foster understanding on topics of mutual interest" (GM1, D3); "we take pride in being an institution that engages in open and constructive dialogue with its stakeholders to refine our CSR strategy" (GM1, D1).

Nevertheless, the CSR perceptions and its influence on stakeholder and shareholder's debate revealed an enriching debate; in fact, shareholders' interviews showed some contradictory statements and opinions in this regard especially GM2: "from a theoretical shareholders' perspective, there is no conflict between the CSR agenda and shareholders. The institution and its shareholders are in the same place" (GM2). Then when questioned about the shareholders being part of the stakeholders GM2 answered: "everybody is working for the shareholders, without shareholders' money we have nothing and thus, management should only do what the shareholders want to be done", giving some insights about agency theory; "at the end of the day, he is not a stakeholder, he is the main catalyst of the business; management, therefore, should focus on its discussions with the shareholders for the setting of the CSR strategy". Then, when asked to elaborate on that matter, he added: "personally, I always refused to put the stakeholders and the shareholders in the same equation. This applies to the customer as well: he is not a stakeholder, he is the ultimate objective, he is more important" (GM2). For him "there is no debate between shareholders and stakeholders; as a shareholder Bank Audi should reflect on me. And management will be 100\% accountable for everything but we should also take them into consideration". And finally, he concluded that: "for me there is no alignment between shareholders' and stakeholders' interests; in fact, there is no interest for stakeholders with us because everything we are doing is by the book and respecting the law" (GM2). Clearly this is not the case with GM1 who preside the CSR committee and is involved in every step of the yearly stakeholders' panel.

We have here some interesting results regarding some divergence of opinions inside the same board, but this is only normal; the legitimacy quest is the ultimate objective for any given CSR strategy and balancing between shareholders' interest and those of stakeholders' is not always an obvious matter as Smith (2003) confirmed.

\section{Discussion and Conclusion}

"Globalization has increased calls for corporations to use firms' resources to help alleviate a wide variety of social problems" (Hillman \& Keim, 2001, p. 125), taking into consideration the lack of governmental support and ability to deal with such problems. Jensen (2002, p. 239) argues that "social welfare is maximized only when all companies in the economy maximize total firm value". Therefore, every company should be guided by a single objective 
of wealth creation which implies that maximizing shareholders' wealth will ultimately lead to maximizing social welfare. GM2 is not far from this kind of thinking; he also presents some critics: CSR investments represent a theft and political subversion, executives take money and resources that would otherwise go to employees, owners or clients which indeed sounds like another tax burden.

According to the stakeholder theory, organizations should be accountable towards their stakeholders; in fact, the term "accountability" frequently relates to this theory and the literature considers how one focal organization delivers its accountability to its various stakeholders (Smith, 2008). In fact, an organization must be able to balance conflicting interests of those stakeholders in its external environment with those stakeholders in its internal environment. Because, even though the stakeholder theory's ultimate objective is the organization continuity, it must be achieved by balancing the interests of all stakeholders including the shareholders, whose interests are usually addressed through profits (Smith, 2003). In fact, the CSR strategy of Bank Audi is trying to balance the interest of both internal and external stakeholders taking into consideration that this is not an easy task.

Furthermore, Suchman' (1995) view of moral legitimacy as a positive normative evaluation of the organization and its activities, resulting from explicit public discussion to gain this type of legitimacy through their vigorous participation in these discussions, is applied within Bank Audi in their yearly stakeholders' panel. In this panel deliberative communication and rational arguments are used to persuade or listen to stakeholders' needs confirming what Palazzo and Scherer (2006) dictate in managing moral legitimacy.

In fact, Clarkson (1995, p. 107) asserts that "the survival and continuing profitability of the corporation depends upon its ability to fulfil its economic and social purpose, which is to create and distribute wealth or value sufficient to ensure that each primary stakeholder group continues as part of the corporation's stakeholder system". In that regard, firms can be more successful by developing relationships with customers, employees, communities, and governments (Harrison \& St. John, 1996; Kotter \& Heskett, 1992). The yearly panel created by Bank Audi and the categorization of their internal and external stakeholders takes all of the above into consideration.

Regarding the debate between shareholders and stakeholders on social issues, it is clear that building better relations with primary stakeholders like employees, customers, suppliers, and communities (Freeman, 1984) could lead to increased financial returns by helping firms develop intangible but valuable assets which can be sources of competitive advantage, Bank Audi is very aware of that and of the benefits that he could gain such as improving its image/reputation, attracting investors, lowering the cost of capital, improving the retention of existing employees, and improving the relationship with stakeholders in order to gain their support and approval confirming the work of Gray et al. (1996) and Deegan (2009).

Finally, in the context of the agency theory, CSR involves high costs for shareholders; managers are perceived as inefficient and incapable of enabling social change, and CSR is argued to be a diversion of scarce firm resources toward unproductive activities, this was part of the debate mentioned above within Bank Audi. The agency approach indicates a negative effect of CSR on prospective cash flows and firm variability, implying lower shareholder wealth. However, on the context of the stakeholder theory and RBV lenses, CSR is perceived 
to financially benefit shareholders through its positive impact on firm stakeholders. In addition, studies have shown that consumers identify more readily with firms with a good record of social responsibility (Bhattacharya \& Sen, 2003; Brown \& Dacin, 1997).

On the other hand, CSR's outcomes can be potentially difficult for shareholders to verify and evaluate; it can be prone to misuse by managers due to information asymmetries between them and their principals (Barnett, 2007). Managers could grab the opportunity to engage in philanthropic activities that may elevate their own personal status in communities (Aupperle, Carroll, \& Hatfield, 1985; McWilliams \& Siegel 1997). This issue is very clear within the discussed opinion of GM2. Furthermore, as Zattoni (2011) argued, investments in CSR may also indicate that managers have slack resources at their disposal but are not able to find an economically productive use for them.

While the stakeholder theory is built on the demand of internal and external stakeholders for companies to behave responsibly, the legitimacy theory emphasizes a social contract between the business and society (Deegan, 2006; Hinson et al. 2010). An organization needs to ensure that these terms are not breached in order to maintain a good state of legitimacy for the organization through which society allows the organization to exist. Therefore, maximizing shareholder value while being socially responsible to a large number of stakeholders, should be the ultimate goal of Bank Audi CSR strategy.

Bank Audi must include more explicitly in its CSR strategy, the moral part of legitimacy through increasing explicit public discussion. It should enlarge its general meeting with stakeholders and increase its frequency creating an environment of trust internally and externally. In fact, CSR in the banking sector has become a firm strategic tool of legitimacy while recognizing stakeholders' interests within the primacy of shareholders' interests. This should be clearer within the Bank CSR strategy and clearer to all shareholders.

Bank Audi must reinforce communication regarding its CSR strategy to explain this process and to make the objectives clearer to the concerned parties; Information and Communication Technologies (ICT) are key elements in such strategy. Finally, the bank should emphasize the communication internally with its shareholders in order to gain their trust and backup to push the CSR strategy further.

Despite the research limitations around the external validity of the qualitative methods, this research has opened the discussion for future research on the subject. The generalization of the results was never our primary objective; we are well aware that the results presented in this research are very specific to Bank Audi SAL and we openly express our reservation concerning the generalization of our results.

Further research must be done to build and elaborate on our findings, either within the Bank Audi or with other financial institutions in Lebanon. 


\section{References}

Adewale M. T., \& Rahmon, T. A. (2014). Does corporate social responsibility improve an organization's financial performance? - Evidence from Nigerian banking sector. The IUP Journal of Corporate Governance, 13(4), 52-60.

Aupperle, K. E., Carroll, A. B., and Hatfield, J. D. (1985). An empirical examination of the relationship between corporate social responsibility and profitability. Academy of Management Journal, 28(2), 446-463.

Barnett, M. L. (2007). Stakeholder influence capacity and the variability of financial returns to corporate social responsibility. Academy of Management Review, 32(3), 794-816.

Bhattacharya, C. B., \& Sen, S. (2003). Consumer-company identification: A framework for understanding consumers' relationships with companies. Journal of Marketing, 67(2), 76-88.

Bowie, N. E., \& Freeman, R. E. (1992). Ethics and agency theory: An introduction. Oxford, UK: Oxford University Press.

Brown, T. J., \& Dacin, P.A. (1997). The company and the product: Corporate associations and consumer product responses. Journal of Marketing, 61(1), 68-84.

Carroll A. B. (1979). A three-dimensional conceptual model of corporate social performance. Academy of Management Review, 4, 497-505.

Carroll, A. B. (1991). The pyramid of corporate social responsibility: Toward the moral management of organizational stakeholders. Business Horizons, 34(4), 39-48.

Carroll, A. B. (1993). Business and society ethics and stakeholder management ( $2^{\text {nd }}$ ed.). Cincinnati: South-Western College Publishing.

Chaudhury, S. K., Das, S. K., \& Sahoo, P. K. (2011). Practices of corporate social responsibility (CSR) in banking sector in India: An assessment. Research Journal of Economics, Business \& ICT, 4, 76-81.

Chiu, T. K. (2013). Putting responsible finance to work for Citi microfinance. Journal of Business Ethics, 2, 1-16.

Clarkson, M. B. E. (1995). A stakeholder framework for analyzing and evaluating corporate social performance. Academy of Management Review, 20, 92-117.

Deegan, C. (2002). The legitimizing effect of social and environmental disclosures: A theoretical foundation. Accounting, Auditing, \& Accountability Journal, 15(3), 282-311.

Deegan, C. (2006). Legitimacy theory. In Z. Hoque (Eds.). Methodological issues in accounting research: Theories and methods (pp. 161-181). London, UK: Spiramus.

Deegan, C. (2009). Financial accounting theory. North Ryde, NSW: McGraw-Hill Australia Pty Ltd.

Donaldson, T., \& Preston, L. E. (1995). The stakeholder theory of the corporation: Concepts, evidence and implications. Academy of Management Review, 20(1), 65-91.

Dujmovic, M., Sinkovic, D., \& Vitasovic, A. (2010). Corporate social responsibility in the banking Proceedings of the International Conference ICES 2010, Economic Developments Perspectives of SEE Region in Global Recession Context. Sarajevo: University of Sarajevo, School of Economics and Business, pp. 181.

Evan, W. M., \& Freeman, R. E. (1988). A stakeholder theory of the modern corporation: Kantian capitalism. In T. L. Beauchamp \& N. E. Bowie (Eds.), Ethical theory and business (pp. 97-106). Englewood Cliffs, NJ: Prentice-Hall.

Freeman R. E. (1984). Strategic management: A stakeholder approach. Marshfield, MA: Pitman.

Freeman, R. E. (1994). A stakeholder theory of the modern corporation. In T. L. Beauchamp \& N. E. Bowie (Eds.), Ethical theory and business (pp. 66-76). Englewood Cliff, NJ: Prentice-Hall.

Freeman, R. E., \& Reed, D. L. (1983). Stockholders and stakeholders: A new perspective on corporate governance. California Management Review, 25(3), 88-106.

Friedman, M. (1962). Capitalism and Freedom. Chicago: University of Chicago Press.

Gray, R., Owen, D., \& Adams, C. (1996). Accounting and accountability: Changes and challenges in corporate social and environmental reporting. Hemel Hempstead: Prentice Hall.

Gray, R., Owen, D., \& Adams, C. (2010). Some theories for social accounting? A review essay and a tentative pedagogic categorization of theorizations around social accounting. Sustainability, Environmental Performance \& Disclosures Advances in Environmental Accounting, 4, 1-54.

Guthrie, J., Petty, R., \& Ricceri, F. (2006). The voluntary reporting of intellectual capital: comparing evidence from Hong Kong and Australia. Journal of Intellectual Capital, 7(2), 254-271. 
Harrison, J., \& St. John C. (1996). Managing and partnering with external stakeholders. Academy of Management Executive, 10, 46-60.

Hasnas, J. (1998). The normative theories of business ethics: A guide for the perplexed. Business Ethics Quarterly, 8(1), 19-42.

Hillman, A. J., \& Keim, G. D. (2001). Shareholder Value, Stakeholder Management, and Social Issues: What's the Bottom Line? Strategic Management Journal, 22(2), 125-139.

Hinson, R., Boateng, R., \& Madichie, N. (2010). Corporate social responsibility activity reportage on bank websites in Ghana. International Journal of Bank Marketing, 28(7), 498-518.

Holme, L., \& Watts, P. (2000). Corporate social responsibility: Making good business sense. Geneva, Switzerland: World Business Council for Sustainable Development.

Jensen, M. (2002). Value maximization, stakeholder theory, and the corporate objective function. Business Ethics Quarterly, 12(2), 235-256.

Jones, T. M. (1995). Instrumental stakeholder theory: A synthesis of ethics and economics. Academy of Management Review, 20(1), 404-437.

Jones, T. M., \& Wicks, A. C. (1999). Convergent stakeholder theory. Academy of Management Review, 24(2), 206-221.

Kotter J., \& Heskett, J. L. (1992). Corporate culture and performance. New York: Free Press.

Kuznetsov, A., \& Kuznetsova, O. (2012). Business legitimacy and the margins of corporate social responsibility in the Russian context. International Studies of Management \& Organization, 42(3), 35-48.

Lindblom, C. K. (1994). The implications of organizational legitimacy for corporate social performance and disclosure. Paper presented at the Critical perspectives on accounting conference, New York.

McWilliams, A., \& Siegel, D. (1997). Event studies in management research: Theoretical and empirical issues. Academy of Management Journal, 40(3), 626-657.

Moir, L. (2001). What do we mean by corporate social responsibility? Corporate Governance, 1(2), 16-22.

Palazzo, G., \& Scherer, A. G. (2006). Corporative legitimacy as deliberation: A communicative framework. Journal of Business Ethics, 66, 71-88.

Post, J. E., Preston, L. E., \& Sachs, S. (2002). Managing the extended enterprise: The new stakeholder view. California Management Review, 45(1), 5-28.

Scholtens, B. (2006). Finance as a driver of corporate social responsibility. Journal of Business Ethics, 68(1), 19-33.

Shen, C. H, Wu, M. W., Chen, T. H., \& Fang, H. (2016). To engage or not to engage in corporate social responsibility: Empirical evidence from global banking sector, Economic Modelling, 55, 207-225.

Smith, H. J.(2003). The shareholders vs. stakeholders debate. MIT Sloan Management Review, 44(4), 85-90.

Smith, N. C. (2008). Consumers as drivers of corporate social responsibility. In A. Crane, A. McWilliams, D., Matten, J., Moon, \& D. S. Siegel (Eds.), The Oxford handbook of corporate social responsibility (281-302). New York: The Oxford University Press.

Suchman, M. C. (1995). Managing legitimacy: Strategic and institutional approaches. Academy of Management Review, 20(3), 571-610.

Waddock, S. (2004). Creating corporate accountability: Foundational principles to make corporate citizenship real. Journal of Business Ethics, 50(4), 313-327.

Zattoni, A. (2011). Who should control a corporation? Toward a contingency stakeholder model for allocating ownership rights. Journal of Business Ethics, 103, 255-274. 